\title{
EVALUATION OF OCULAR RESPONSE ANALYZER IN ASSESSMENT OF CORNEAL BIOMECHANICS AND OCULAR PRESSURE IN GLAUCOMA SUSPECT INDIVIDUALS
}

By

Mohammed Salah El-Deen Mohammed, Hisham Fawzy Khalleil,

\author{
AND- Hossam El-Din -Abd El-Moneam Ziada, \\ Department of Ophthalmology, Faculty of Medicine, Al-Azhar University
}

Corresponding author: Mohammed Salah El-Deen Mohammed, Mobile: 01069686406

E-mail: the_vagus22@yahoo.com

\begin{abstract}
Background: The cornea exhibits viscoelastic properties, which give it the quality of hysteresis. Corneal hysteresis $(\mathrm{CH})$ is an important indicator of the biomechanical properties of the cornea.

Objective: To evaluate the effect of ocular response Analyzer in assessment of corneal biomechanics and intraocular pressure in glaucoma suspect individuals.

Individuals and Methods: We conducted our study on 60 eyes which was divided into 30 eyes of normal populations and 30 eyes of glaucoma suspect patients.

Results: Elevation of intraocular pressure (IOP) led to decrease in corneal biomechanics as corneal hysteresis $(\mathrm{CH})$ and corneal resistance factor $(\mathrm{CRF})$.

Conclusion: Increase of IOP led to decrease in corneal biomechanics as $\mathrm{CH}$ and CRF.

Keywords: Goldmann applanation tonometry, laser peripheral iridotomy, Corneal hysteresis

\section{INTRODUCTION}

Ophthalmologists have long recognized ocular hypertension (IOP>21 $\mathrm{mm} \mathrm{Hg}$ ) as a risk factor for glaucoma. Other factors include African Caribbean race, a family history of glaucoma, and advanced age. The Ocular Hypertension Treatment Study helped define baseline ocular factors that increase the risk of converting to glaucoma in eyes in which the pressure is elevated and the optic disc and visual field are normal. Those risk factors include a central corneal thickness

of $>556 \mu \mathrm{m}$, a C/D $>0.4$, and a largerthan-average pattern standard deviation on an otherwise normal threshold visual field. Other ocular and systemic risk factors are diabetes, hypertension, high myopia, cardiovascular disease, and migraine/ vasospasm, all of which the practitioner must take into account (Suzuki et al., 2006).

The diurnal variation for normal eyes is between 3 and $6 \mathrm{mmHg}$ which is more in the morning. The variation may increase in glaucomatous eyes. During the
\end{abstract}


night, intraocular pressure may not decrease despite the slower production of aqueous humor. In the general population, IOP ranges between 10 and $21 \mathrm{~mm} \mathrm{Hg}$ with a mean of about 15 or $16 \mathrm{~mm} \mathrm{Hg}$ (plus or minus $3.5 \mathrm{~mm} \mathrm{Hg}$ during a 24hour cycle). In glaucoma patients, their 24-hour IOP profiles may be different from healthy individuals (Liu and Weinreb, 2011).

Glaucoma suspect is a diagnosis reserved for individuals who do not definitively have glaucoma at the present time but have characteristics suggesting that they are at high risk of developing the disease in the future based on a variety of factors.: ocular hypertension, optic nerve features suggestive of glaucoma, visual field abnormalities, and other characteristics placing them at greater risk than the average population (Ahmad, 2018).

Corneal Hysteresis is an assessment of the ability of the cornea to absorb and dissipate energy. Corneal hysteresis is independently predictive of visual field progression in glaucoma. It is used as a predictor of glaucoma risk and may help to assess the effect of corneal thickness on intraocular pressure. The clinical significance of $\mathrm{CH}$ in the diagnosis and efficacy of glaucoma will become more explicit. In the future, $\mathrm{CH}$ can also play an important role in the diagnosis and treatment of glaucoma (Liang et al., 2018).

In 2005 The Ocular Response Analyzer (ORA) was introduced as a tonometer that uniquely measures and then integrates corneal biomechanical data into its intraocular pressure (IOP) estimates in an effort to improve accuracy of IOP assessment (Medeiros et al., 2013).

This work aimed to evaluate the effect of ocular response analyzer in measurement and assessment of corneal biomechanics, corneal hysteresis, corneal resistance factor and IOP in patients with glaucoma suspect and normal individuals.

\section{PATIENTS AND METHODS}

Sixty eyes of 60 subjects were enrolled. Subjects were selected from Ophthalmology outpatient clinic in AlAzhar University Hospital and Kobri El Kobba Military hospital in Cairo. The study was carried out from April to October 2019. According to the principle of the declaration of Helsinki, the study was explained to the subjects and was asked to sign written informed consents. The study was approved by the ethics board of Al-Azhar University. The study was prospective. Patients were divided into two equal groups: Group A: Normal individuals. Group B: Glaucoma suspects.

\section{Inclusion criteria:}

Age ranged from 30-70 years old of both genders and normal individuals as regard eye.

\section{Exclusion criteria:}

No previous ocular surgery, not known to be glaucoma, and corneal degenerative disease as keratoconus. Methods: Subjects were evaluated by history, examination and investigation.

\section{Statistical Analysis:}

Data were collected, revised, coded and entered to the Statistical Package for Social Science (SPSS) version 20. Qualitative data were presented as number 
and percentages, while quantitative data were presented as mean, standard deviations and ranges.

The comparison between two independent groups with quantitative data and parametric distribution was done by using Independent t-test and qualitative data by Chi-square test.
Pearson correlation coefficients were used to assess the relation between two studied parameters in the same group. The confidence interval was set to $95 \%$ and the margin of error accepted was set to $5 \%$. So, the p-value was considered significant when: $\mathrm{P}>0.05$.

\section{RESULTS}

There was no statistically significant difference between the study groups as regard age and sex. (Table 1)

Table (1): Demographic results of the study groups in $\%$.

\begin{tabular}{|c|c|c|c|c|}
\hline \multicolumn{4}{|c|}{ parameters } & Total no. $=60$ \\
\hline \multirow{2}{*}{\multicolumn{2}{|c|}{ Sex }} & \multicolumn{2}{|l|}{ Female } & $29(48.3 \%)$ \\
\hline & & \multicolumn{2}{|l|}{ Male } & $31(51.7 \%)$ \\
\hline \multirow{2}{*}{\multicolumn{2}{|c|}{ Age }} & \multicolumn{2}{|l|}{ Mean \pm SD } & $45.57 \pm 7.67$ \\
\hline & & \multicolumn{2}{|l|}{ Range } & $32-62$ \\
\hline \multirow{2}{*}{\multicolumn{2}{|c|}{ CD ratio }} & \multicolumn{2}{|l|}{ Mean \pm SD } & $0.75 \pm 0.07$ \\
\hline & & \multicolumn{2}{|l|}{ Range } & $0.7-0.9$ \\
\hline & & Control group & Patients group & \multirow{2}{*}{ P-value } \\
\hline & & No. $=30$ & No. $=30$ & \\
\hline \multirow{2}{*}{ Sex } & Female & $16(53.3 \%)$ & $13(43.3 \%)$ & \multirow{2}{*}{0.438} \\
\hline & Male & $14(46.7 \%)$ & $17(56.7 \%)$ & \\
\hline \multirow{2}{*}{ Age } & Mean \pm SD & $43.83 \pm 7.23$ & $47.30 \pm 7.83$ & \multirow{2}{*}{0.080} \\
\hline & Range & $32-60$ & $36-62$ & \\
\hline
\end{tabular}

*: Chi-square test; $\bullet$ : Independent t-test

This table shows no statistically significant difference between the study groups as regard to age ( $\mathrm{p}$-value $=0.080)$.

There was a statistically significant difference between the study groups as regard visual acuity. (Table 2) 
Table (2): Comparison between IOPcc and IOPg in control group and patient group

\begin{tabular}{|c|c|c|c|c|}
\hline \multirow{2}{*}{\multicolumn{2}{|c|}{$\begin{array}{ll}\text { Parameters } & \text { Groups } \\
\end{array}$}} & Control group & Patients group & \multirow{2}{*}{ P-value } \\
\hline & & No. $=30$ & No. $=30$ & \\
\hline \multicolumn{5}{|c|}{ Baseline } \\
\hline \multirow{2}{*}{$\mathrm{IOPcc}$} & Mean \pm SD & $16.76 \pm 2.65$ & $22.85 \pm 3.67$ & \multirow{2}{*}{0.001} \\
\hline & Range & $10.4-20.3$ & $16.4-32.1$ & \\
\hline \multirow{2}{*}{$\mathrm{IOPg}$} & Mean \pm SD & $15.47 \pm 2.44$ & $20.67 \pm 3.42$ & \multirow{2}{*}{0.001} \\
\hline & Range & $10.2-19.3$ & $16.1-30.2$ & \\
\hline \multicolumn{5}{|l|}{$\begin{array}{l}\text { Follow } \\
\text { up }\end{array}$} \\
\hline \multirow{2}{*}{ IOPcc } & Mean \pm SD & $16.62 \pm 2.33$ & $22.62 \pm 3.49$ & \multirow{2}{*}{0.001} \\
\hline & Range & $12.1-20.1$ & $16.1-30.1$ & \\
\hline \multirow{2}{*}{$\mathrm{IOPg}$} & Mean \pm SD & $15.27 \pm 2.45$ & $20.62 \pm 3.40$ & \multirow{2}{*}{0.001} \\
\hline & Range & $10.2-19.1$ & $16-30.1$ & \\
\hline \multicolumn{5}{|l|}{$\begin{array}{l}\text { \% of } \\
\text { change }\end{array}$} \\
\hline \multirow{2}{*}{ IOPcc } & Mean \pm SD & $0.05 \pm 12.14$ & $-0.91 \pm 1.35$ & \multirow{2}{*}{0.010} \\
\hline & Range & $-17.20-61.54$ & $-6.23-1.05$ & \\
\hline \multirow{2}{*}{$\mathrm{IOPg}$} & Mean \pm SD & $-1.33 \pm 1.20$ & $-0.25 \pm 0.58$ & \multirow{2}{*}{0.001} \\
\hline & Range & $-5.43-0.00$ & $-1.47-0.98$ & \\
\hline
\end{tabular}

$\because$ Independent t-test

$\neq$ : Mann-Whitney test

There was significant different between the study group as regard IOPcc and IOPg, \% of change in IOPcc and \% of change in IOPg. (Table 1)

Table (3): Comparison between $\mathrm{CH}$ and $\mathrm{CRF}$ in control and patient groups

\begin{tabular}{|c|c|c|c|c|}
\hline \multirow{2}{*}{\multicolumn{2}{|c|}{$\begin{array}{ll}\text { Parameters } & \text { Groups } \\
\end{array}$}} & Control group & Patients group & \multirow{2}{*}{ P-value } \\
\hline & & No. $=30$ & No. $=30$ & \\
\hline \multicolumn{2}{|c|}{ Baseline } & & & \multirow{3}{*}{0.001} \\
\hline \multirow{2}{*}{$\mathrm{CH}$} & Mean \pm SD & $9.47 \pm 0.88$ & $7.63 \pm 1.34$ & \\
\hline & Range & $7.9-11.3$ & $5.3-10$ & \\
\hline \multirow{2}{*}{ CRF } & Mean \pm SD & $9.34 \pm 0.87$ & $8.17 \pm 1.71$ & \multirow{2}{*}{0.002} \\
\hline & Range & $7.5-11.1$ & $5.6-11.2$ & \\
\hline \multicolumn{5}{|c|}{$\begin{array}{l}\text { Follow } \\
\text { up }\end{array}$} \\
\hline \multirow{2}{*}{$\mathrm{CH}$} & Mean \pm SD & $9.41 \pm 0.86$ & $7.56 \pm 1.35$ & \multirow{2}{*}{0.001} \\
\hline & Range & $7.9-11.2$ & $5.2-10$ & \\
\hline \multirow{2}{*}{$\mathrm{CRF}$} & Mean \pm SD & $9.31 \pm 0.89$ & $8.12 \pm 1.70$ & \multirow{2}{*}{0.001} \\
\hline & Range & $7.4-11.1$ & $5.6-11.1$ & \\
\hline \multicolumn{5}{|c|}{$\begin{array}{l}\text { \% of } \\
\text { change }\end{array}$} \\
\hline \multirow{2}{*}{$\mathrm{CH}$} & Mean \pm SD & $-0.48 \pm 5.40$ & $0.64 \pm 18.51$ & \multirow[b]{2}{*}{0.473} \\
\hline & Range & $-14.15-20.88$ & $-48.00-50.00$ & \\
\hline \multirow{2}{*}{ CRF } & Mean \pm SD & $0.34 \pm 11.26$ & $-0.69 \pm 0.94$ & \multirow{2}{*}{0.803} \\
\hline & Range & $-27.03-33.73$ & $-3.13-0.91$ & \\
\hline
\end{tabular}

$\bullet:$ Independent t-test 


\section{EVALUATION OF OCULAR RESPONSE ANALYZER IN ASSESSMENT...}

There was a significant difference between the study groups as regard $\mathrm{CH}$ and CRP, and non significant difference between the study groups as regard \% of change in $\mathrm{CH}$ and CRP. (Table 4)

Table (4): Comparison between VArt and VAlt in control and patient groups

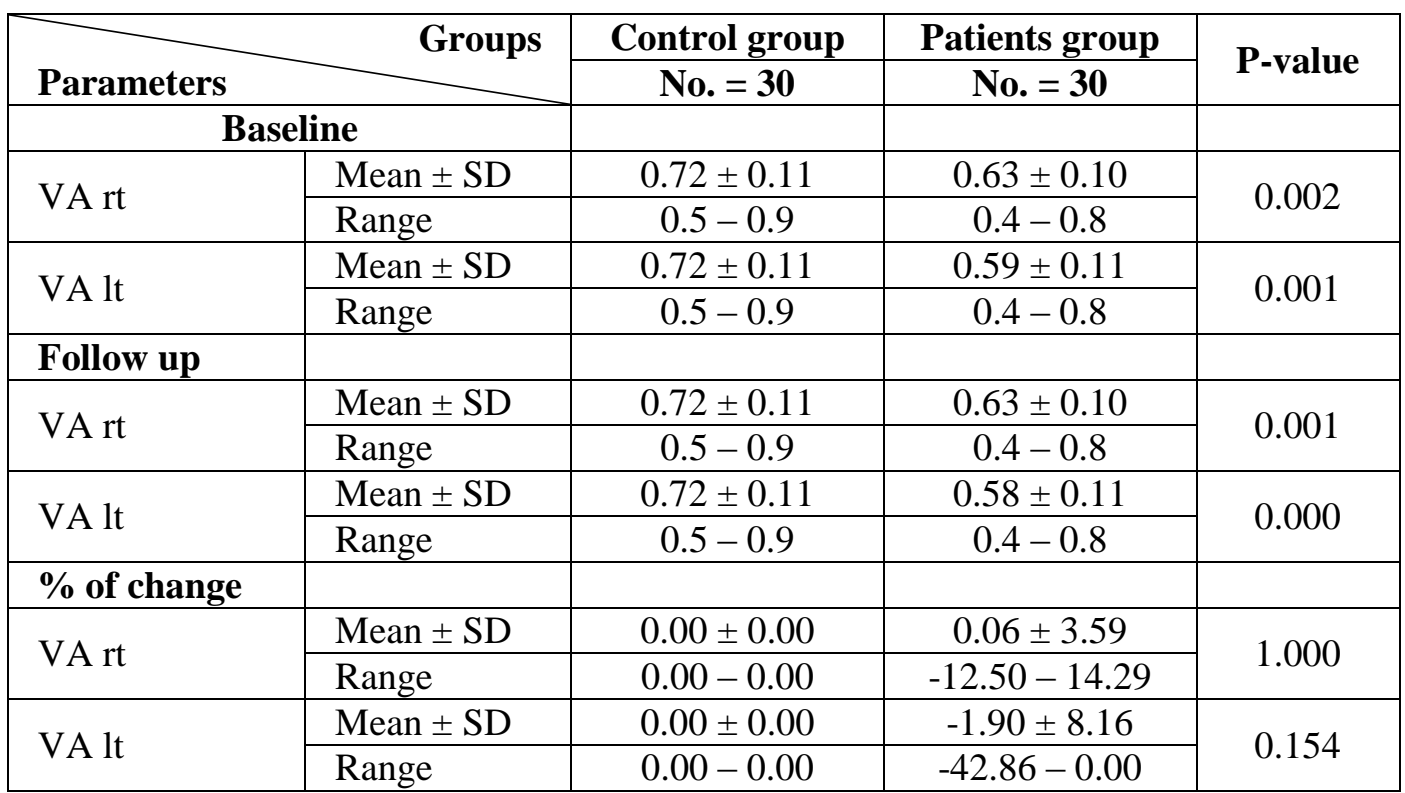

$\bullet:$ Independent t-test

There was a non significant difference between the study groups as regard visual acuity and significant difference between baseline IOPg and their follow up, baseline IOPcc, $\mathrm{CH}$, CRF, VA and their follow up. (Table 5). 
Table (5): Comparison between baseline parameters as IOPcc, IOPg, CH, CRF, VA rt and VA It and their follow up values in control group

\begin{tabular}{|c|c|c|c|c|}
\hline \multirow{2}{*}{\multicolumn{2}{|c|}{$\begin{array}{l}\text { Control Groups } \\
\text { Parameters }\end{array}$}} & \multicolumn{2}{|c|}{ Control group } & \multirow{2}{*}{ P-value } \\
\hline & & \multirow{2}{*}{$\begin{array}{c}\text { Baseline } \\
16.76 \pm 2.65\end{array}$} & \multirow{2}{*}{$\begin{array}{c}\text { Follow up } \\
16.62 \pm 2.33\end{array}$} & \\
\hline \multirow{2}{*}{ IOPcc } & Mean \pm SD & & & \multirow{2}{*}{0.595} \\
\hline & Range & $10.4-20.3$ & $12.1-20.1$ & \\
\hline \multirow{2}{*}{ IOPg } & Mean \pm SD & $15.47 \pm 2.44$ & $15.27 \pm 2.45$ & \multirow{2}{*}{0.000} \\
\hline & Range & $10.2-19.3$ & $10.2-19.1$ & \\
\hline \multirow{2}{*}{$\mathrm{CH}$} & Mean \pm SD & $9.47 \pm 0.88$ & $9.41 \pm 0.86$ & \multirow{2}{*}{0.544} \\
\hline & Range & $7.9-11.3$ & $7.9-11.2$ & \\
\hline \multirow{2}{*}{ CRF } & Mean \pm SD & $9.34 \pm 0.87$ & $9.31 \pm 0.89$ & \multirow{2}{*}{0.904} \\
\hline & Range & $7.5-11.1$ & $7.4-11.1$ & \\
\hline \multirow{2}{*}{ VA rt } & Mean \pm SD & $0.72 \pm 0.11$ & $0.72 \pm 0.11$ & \multirow{2}{*}{-} \\
\hline & Range & $0.5-0.9$ & $0.5-0.9$ & \\
\hline \multirow{2}{*}{ VA lt } & Mean \pm SD & $0.72 \pm 0.11$ & $0.72 \pm 0.11$ & \multirow{2}{*}{-} \\
\hline & Range & $0.5-0.9$ & $0.5-0.9$ & \\
\hline \multirow{2}{*}{ IOPcc } & Mean \pm SD & $22.85 \pm 3.67$ & $22.62 \pm 3.49$ & \multirow{2}{*}{0.003} \\
\hline & Range & $16.4-32.1$ & $16.1-30.1$ & \\
\hline \multirow{2}{*}{ IOPg } & Mean \pm SD & $20.67 \pm 3.42$ & $20.62 \pm 3.40$ & \multirow{2}{*}{0.018} \\
\hline & Range & $16.1-30.2$ & $16-30.1$ & \\
\hline \multirow{2}{*}{$\mathrm{CH}$} & Mean \pm SD & $7.63 \pm 1.34$ & $7.56 \pm 1.35$ & \multirow{2}{*}{0.778} \\
\hline & Range & $5.3-10$ & $5.2-10$ & \\
\hline \multirow{2}{*}{ CRF } & Mean \pm SD & $8.17 \pm 1.71$ & $8.12 \pm 1.70$ & \multirow{2}{*}{0.001} \\
\hline & Range & $5.6-11.2$ & $5.6-11.1$ & \\
\hline \multirow{2}{*}{ VA rt } & Mean \pm SD & $0.63 \pm 0.10$ & $0.63 \pm 0.10$ & \multirow{2}{*}{0.423} \\
\hline & Range & $0.4-0.8$ & $0.4-0.8$ & \\
\hline \multirow{2}{*}{ VA lt } & Mean \pm SD & $0.59 \pm 0.11$ & $0.58 \pm 0.11$ & \multirow{2}{*}{0.211} \\
\hline & Range & $0.4-0.8$ & $0.4-0.8$ & \\
\hline
\end{tabular}

There was a significant difference in IOPcc, IOPg and CRP in patient group between baseline and their follow up and non significant difference in $\mathrm{CH}$, VA rt, VA lt in patient group between baseline and their follow up ( $p$ value > 0.05). (Table 6). 
EVALUATION OF OCULAR RESPONSE ANALYZER IN ASSESSMENT... 821

Table (6): Comparison between $\mathrm{CD}$ ratio and it relation to other parameters as IOPcc, $\mathrm{CH}, \mathrm{CRF}, \mathrm{VA}$ and age, their up, \% of change

\begin{tabular}{|l|c|c|}
\hline Parameters & r & P-value \\
\hline Age & -0.302 & 0.184 \\
\hline baseline & & \\
\hline IOPcc & -0.059 & 0.799 \\
\hline IOPg & 0.133 & 0.565 \\
\hline CH & 0.249 & 0.276 \\
\hline CRF & 0.236 & 0.304 \\
\hline VA rt & 0.084 & 0.717 \\
\hline VA lt & 0.099 & 0.668 \\
\hline Follow up & & \\
\hline IOPcc & -0.062 & 0.788 \\
\hline IOPg & 0.140 & 0.546 \\
\hline CH & 0.169 & 0.463 \\
\hline CRF & 0.292 & 0.199 \\
\hline VA rt & 0.084 & 0.717 \\
\hline VA lt & 0.027 & 0.907 \\
\hline \% of change & & \\
\hline IOPcc & 0.133 & 0.566 \\
\hline IOPg & 0.149 & 0.519 \\
\hline CH & -0.096 & 0.678 \\
\hline CRF & 0.355 & 0.115 \\
\hline VA lt & -0.209 & 0.362 \\
\hline
\end{tabular}

Spearman correlation coefficient

\section{DISCUSSION}

The human cornea is a viscoelastic tissue that can be described by two principal properties: A static resistance component (characterized by the CRF), for which deformation is proportional to applied force, and a dynamic resistance component (characterized by $\mathrm{CH}$ ), for which the relationship between deformation and applied force depends on time. Both $\mathrm{CH}$ and the $\mathrm{CRF}$ are measured using a dynamic bidirectional applanation process using the ORA (Ambrósio et al., 2013).

The value of $\mathrm{CH}$ reflects the ability of corneal tissue to absorb and release energy during bidirectional flattening. It is an important biomechanical parameter of the cornea. The $\mathrm{CH}$ value of healthy adults is about $11 \mathrm{mmHg}$. The measurement of $\mathrm{CH}$ is reproducible and different. People have different $\mathrm{CH}$ values, which are determined by the shape of the individual's cornea. The study found that all types of glaucoma, including primary open angle glaucoma, angle-closure glaucoma, normal tension glaucoma, congenital glaucoma, binocular asymmetrical glaucoma, $\mathrm{CH}$ values are lower than normal people. Therefore, $\mathrm{CH}$ is a good indicator of glaucoma diagnosis and screening. Lower $\mathrm{CH}$ values are associated with thinner retinal nerve fiber layer (RNFL), larger linear cup/disk ratio (LCDR) and degree of optic disc defect. A 
lower $\mathrm{CH}$ value can also result in a lower visual field index. $\mathrm{CH}$ and the basic intraocular pressure play a synergistic role in the progression of glaucoma. The study found that $\mathrm{CH}$ can change with changes in basic intraocular pressure, means $\mathrm{CH}$ increases when intraocular pressure decreases, while the $\mathrm{CH}$ decreases conversely when intraocular pressure increases.. $\mathrm{CH}$ has its limitations, such as corneal damage or corneal surgery, but in general, $\mathrm{CH}$ is a risk factor for glaucoma progression

Our groups were divided into two equal subgroups: Controlled group of normal individuals, and patients group of glaucoma suspect individuals.

Mean IOP was statistically significant in patients group when compared with control group.

Mean IOPg was statistically significant in patients group when compared with control group.

Mean $\mathrm{CH}$ was statistically significant in patients group when compared with control group.

Kamiya et al. (2012) it was statistically highly significant in patients group when compared with control group.

Hoban et al. (2017) it was statistically highly significant in patients group when compared with control group.

Meanwhile Jin et al. (2016) disagreed with our results as they noted that there was no statistically significant difference between the control and diseased groups regarding $\mathrm{CH}$ values.

Mean $\mathrm{CH}$ in control group was $9.41 \pm$ $0.5 \mathrm{mmHg}$ and mean $\mathrm{CH}$ in diseased group was $9.44 \pm 0.62 \mathrm{mmHg}$.
Wei et al. (2014) it was statistically highly significant in patients group when compared with control group.

In our study the mean CRF in the control group was $9.34 \pm 0.87 \mathrm{mmHg}$ in comparison with the mean $\mathrm{CH}$ in diseased group which was $8.17 \pm 1.71 \mathrm{mmHg}$.

It was statistically highly significant in patients group when compared with control group.

Zuo et al. (2019) it was statistically highly significant in patients group when compared with control group.

Elmazara et al. (2017) agreed with our results as they mentioned in their results that the mean CRF value of the control group (group A) was $7.1731 \pm 0.97952$ $\mathrm{mmHg}$ in comparison with 8.6902 $\pm 1.25195 \mathrm{mmHg}$ in diseased group (group B).

Elmazara et al. (2017) it was statistically highly significant in patients group when compared with control group.

Meanwhile Katz et al. (2018) disagreed with our results as they noted that there was no statistically significant difference between the control and diseased groups regarding CRF values.

Mean CRF in control group was $8.81 \pm$ $0.45 \mathrm{mmHg}$ and mean $\mathrm{CRF}$ in diseased group was $9.11 \pm 0.52 \mathrm{mmHg}$.

Wei et al. (2014) it was statistically highly significant in patients group when compared with control group.

Abitbol et al. (2010) it was statistically highly significant in patients group when compared with control group.

In our study the mean VA in the control group was $0.72 \pm 0.11$ in 
comparison with the mean VA in diseased group which was $0.63 \pm 0.10$.

It was statistically highly significant in patients group when compared with control group.

Zuo et al. (2019) it was statistically highly significant in patients group when compared with control group.

Allam and Khalil (2015) it was statistically highly significant in patients group when compared with control group.

Wei et al. (2014) it was statistically highly significant in patients group when compared with control group.

\section{CONCLUSION}

Our study reported that elevation of IOP leads to decrease in corneal biomechanics as $\mathrm{CH}$ and $\mathrm{CRF}$. Also there is significant difference in IOP, $\mathrm{CH}, \mathrm{CRF}$, VA, FUNDUS (CD ratio) between glaucoma suspects versus normal individuals. Where IOP increase but $\mathrm{CH}$, $\mathrm{CRF}$ decrease in glaucoma suspect individuals, $\mathrm{CD}$ ratio more than 0.5 in glaucoma suspect, optic disc may show a notch.

\section{REFERENCES}

1. Ahmad SS (2018): Glaucoma suspects: a practical approach. Taiwan Journal of Ophthalmology, 8(2):74-81.
2. Ambrósio R, Ramos I, Luz A, Faria FC, Steinmueller A, Krug M, Belin MW and Roberts CJ (2013): Dynamic ultra high speed Scheimpflug imaging for assessing corneal biomechanical properties. Revista Brasileira de Oftalmologia, 72(2):99-102.

3

5. Hoban K, Peden R, Megaw R, Halpin $P$ and Tatham AJ (2017): 24-Hour contact lens sensor monitoring of intraocular pressurerelated profiles in normal-tension glaucoma and rates of disease progression. Ophthalmic Research, 57(4):208-15.

6. Liang L, Zhang R and He LY (2018): Corneal hysteresis and glaucoma. International Ophthalmology, 1-8.

7. Liu JH and Weinreb RN (2011): "Monitoring intraocular pressure for $24 \mathrm{~h}$ ". Br J Ophthalmol, 95 (5): 599-600.

8. Medeiros FA, Meira-Freitas D, Lisboa R, Kuang TM, Zangwill LM and Weinreb RN (2013): Corneal hysteresis as a risk factor for glaucoma progression: a prospective longitudinal study. Ophthalmology, 120(8):1533-40.

9.Suzuki Y, Iwase A, Araie M, Yamamoto T, Abe $\mathbf{H}$, Shirato $S$, Kuwayama $\mathbf{Y}$, Mishima HK, Shimizu H, Tomita G and Inoue $Y$ (2006): Risk factors for open-angle glaucoma in a Japanese population: the Tajimi Study. Ophthalmology, 113(9):1613-7. 


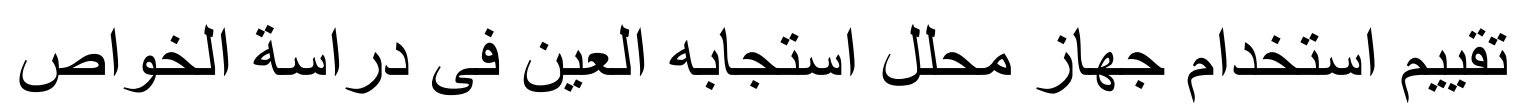

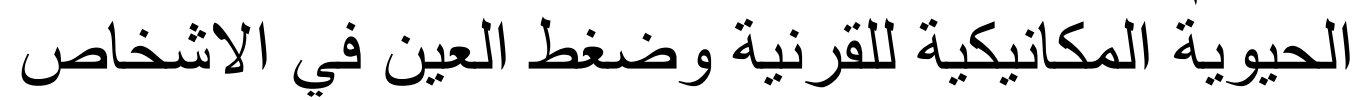

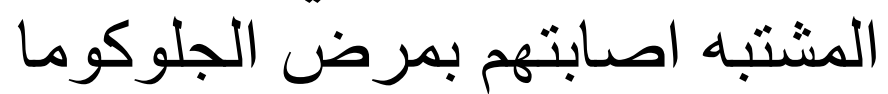

محمد صلاح الاين محد محمد ، هثام فوزى خليل، حسام عبد المنعم زياده قسم طب و جراحة العين، كلية الطب -جامعة الازهر، القاهرة

خلفية البحث: للقرنية خو اص المرونة واللزوجة، والتي تمنحها خاصية التباطؤ. التباطؤ القرني هو مؤشر مهم على الخواص الميكانيكية الحيوية للقرنية.

الهذف من البحث: تقييم تأثير محلل استجابة العين في قياس وتقييم الميكانيكا الحيوية القرنية المشتبه

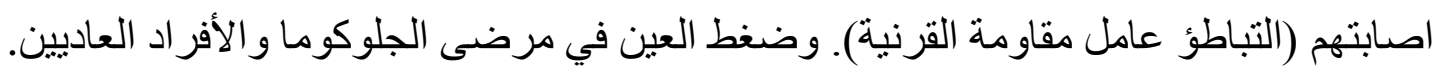

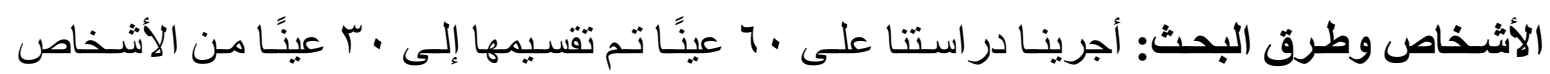
الطبيعيين، و ·r ع عينًا من المرضى المشتشبه باصابتهم بالجلوكوما.

نتائج البحث: ذكرت دراستنا أن ارتفاع ضغط العين يؤدي إلى انخفاض في الميكانيكا الحيوية القرنية

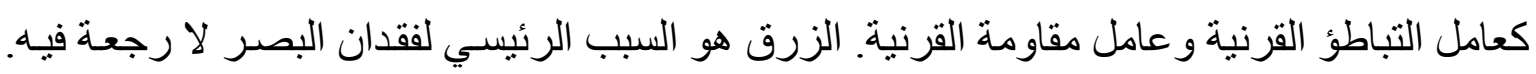

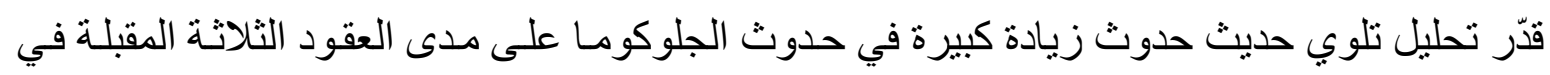

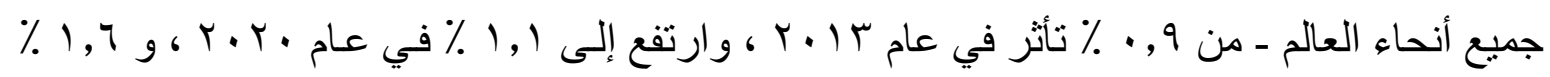

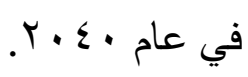

الأستنتاج: ذكرت دراستنا أن ارتفاع ضغط العين يؤدي إلى انخفاض في الميكانيكا الحيوية القرنية متل

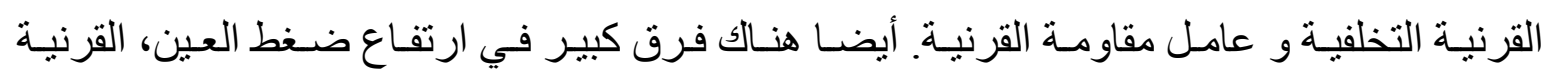

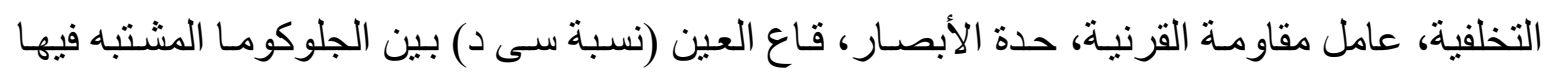

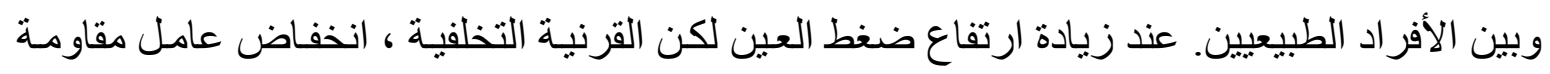

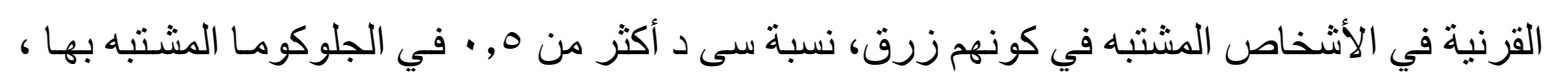

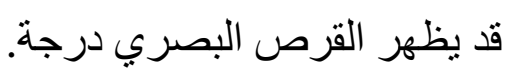

